\title{
The Role of Bahasa Indonesia Lecturer's Creativity to be Partner with Dignified Students
}

\author{
Aceng Hasani \\ University of Sultan Ageng Tirtayasa \\ Serang, Indonesia \\ aceng.hasani@yahoo.co.id
}

\begin{abstract}
The Role of Indonesian lecturer is to realize student and character generation character required of teachers; teachers who not only have the intellectual ability, but also the ability to be emotionally and spiritually. Character formation of students who require professional lecturers. Indonesian lecturers who are not professionals other than teachers who (1) has a broad knowledge of the language; (2) have the language skills; $(3)$ is able to make a good planning; (4) able to carry out learning activities well, is able to carry out learning approaches and methods appropriate to the objectives to be achieved, (5) is able to empower learners in the learning; (6) has a quality culture, behavior based on the professionalism of teachers; (7) has a disclosure; (8) strive to increase student participation in learning; (9) the assessment and continuous improvement; (10) to establish communication and interaction with students; (11) have accountability; (12) being critical and dare to resist the will of the less instructive; (13) be creative in developing and producing works of education; and (14) dare to convince the head of the rector, parents, and community to side with him against some educative educational innovations that tend to be difficult accepted by the layman. Lecturers must cooperate with students and parents as well as a conducive environment that can inspire the student to work and be an example of a good role in everyday life.
\end{abstract}

Keywords - Role Lecturer, Indonesian, Character, and Dignity.

\section{INTRODUCTION}

Currently, the superiority of a nation will depend heavily on the quality of education. If observed carefully nation we agreed that scientific studies above should be observed for the earnest endeavor to continuously improve the quality of education.

National commitments on the development and character formation in education have been listed in [1]. In Article 3 explicitly stated that "the national education serves to develop the ability and character development and civilization of the nation's dignity in the context of the intellectual life of the nation, aim to developing students' potentials in order to become a man of faith and fear of God Almighty, noble, healthy, knowledgeable, skilled, creative, independent, and become citizens of a democratic and full of responsibility."

Students at a young generation will bear the responsibility in advancing civilization and creative excellence of the Indonesian nation. Therefore, their role as subjects of history, critical actors, and creators who determine the future of our nation has to be prepared early and developed in a sustainable manner. Confirmed by the President of the Republic of Indonesia in his speech on the Scout's 52 ${ }^{\text {nd }}$ Anniversary in 2013 that the celebration of 100 years of independence of our nation on the year 2045, our nation has emerged as a leading nation and advanced. The young generation is expected to appear as a major activator of the nation's progress. Young generation expected to be able to write new histories that more impressive and could be something that we proud of.

The purpose of education has been formulated with the requirements above. Stated in [2] that Basic Education purposed to put basic intelligence, knowledge, personality, noble character, also skill to live independently dan follow the higher education. Middle Education purposed to raised intelligence, knowledge, personality, noble character, also skill to live independently dan follow the higher education.

Our educational curriculum has given attention to the formation of students' character. Nevertheless, the practice of education in schools more emphasize on the aspect of intellectual intelligence and knowledge's accumulation. Regard to that, all functionary in education, including Indonesian teachers, have the responsibility to create a characterized students and generation. Be in accordance with the tasks' field that had become his life choice, Indonesian teacher faced with the challenge to improve Bahasa Indonesia's role in developing and constructing of a national character for the younger generation (learners). It must be a collective consciousness of teachers for the use of the Indonesian language, including in education, that growing our concern. Students' language competence both oral and written not encouraging.

Exchanging signs and markers using Bahasa Indonesia that good and right, the using of slang is more practiced by the students, even when speaking at school. Therefore, teachers are required to challenge and empower themselves to become professional teachers. Teachers not only required to have extensive knowledge of the language but more important to have a reliable proficiency so that they are able to portray themselves as a good role model for students. The kind of teachers like this that will be able to inspire students to become a character that intelligent and humane.

\section{CHARACTER AND CHARACTER EDUCATION}


These days, the issue of developing a values-based education so loudly touted, especially in Indonesia. The character is a way of thinking and behaving that become a characteristic of each individual to live and work, both within the family, community, nation, and state. Individuals who have a good character is an individual who can make decisions and be ready to respond to every result of a decision he made [3]. Character education is mentioned as values education, character education, moral education, character education that aims to develop the ability of learners to provide a good or bad decision, maintaining what is good and create all the kindness in every day's life with a vengeance. Ref. [4] has further identified the various characters that need to be owned by learners, i.e religious, honesty, tolerance, discipline, hard work, creative, independent, democratic, curiosity, the spirit of nationalism, love of the homeland, appreciate the achievements, communicative, love peace, love reading, environmental care, social care, and responsibility. These characteristics indicate that the real education is not only to make intelligent learners, but also have manners so that their existence as a member of society becomes meaningful, either for themselves or for society in general.

Characters are of value. A value that is embodied in the form of behavior that is called character. In Islam reference, the very famous and attached values that reflect the character of Nabi Muhammad SAW is (1) Truth, (2) trust, (3) smart, and (4) communicative. Sidik means true, committed to the truth, always say and do the right thing, and strive to uphold the truth. Amanah means honest or trustworthy (both by Muslims and non-Muslims). Fatonah means intelligent, clever, wise, knowledgeable, skilled, and professional. Tabliq means communicative (others easily understand spoken or intended the Prophet). According to [5], four of these values are the essence, not entirely. Prophet Muhammad is also known for his patience, toughness, and other various noble characters.

The question that needs to be asked is how the characteristics of the character of the young generation that we want to develop? Characters that need to be developed is the character of the young generation that consistent with the national character, the personality of Indonesia.

Indonesia has a personality that characterizes our nation, which is different from other nations, which crystallized in the Pancasila. As the foundation of the country, Pancasila has been discussed even before Indonesia declared its independence. It takes a process of discussion and long debate and ultimately obtained a final decision as the text of Pancasila as we know it today.

Character education, looked by its definition, implies (1) education integrated with the learning that occurs in all subjects; (2) aimed at strengthening and development of the child's behavior as a whole. The assumption is that a child is a human organism that has the potential to be strengthened and developed; and (3) strengthening and development of behavior based on the value referred to the school (institution) [5].

according to that, character education is not just to teach what is right and what is wrong. Moreover, character education inculcates the habit (habituation) about what is the good things so that learners become familiar (cognitive) about what is right and wrong, able to feel (effective) which is a good value and accustomed to doing it (psychomotor). In other words, education of good character should involve not only the aspect of "good knowledge (moral knowing), but also" good in feeling or loving a good (moral feeling), and good behavior (moral action) [6]. character education emphasizes on habit or custom which constantly practiced and performed. The ultimate purpose of the implementation of character education primarily is to increase the good in the learner, which is to be young people who are intelligent, caring, and put good values in his actions. To achieve these objectives, [6] to develop a program Character Education Partnership (CEP). Superior program that introduces by Lickona through CEP are eleven principles of effective education character, yakni (1) promote core ethical values as the basis of good character; (2) define character comprehensively to include thinking, feeling, and behavior; (3) use a comprehensive intentional, proactive, and effective approach; (4) create a caring school community; (5) provide students with opportunities to engage in moral action; (6) provide a meaningful and challenging curriculum that helps all students to succeed; (7) foster students' intrinsic motivation to learn and to be good people; (8) engage school staff as professionals in a learning and moral community; (9) foster shared moral leadership and long-term support for character education; (10) engage families and community members as partners in character education; dan (11) evaluate the character of the school, its staff, and its students to inform the character education effort.

There are three educational paths, namely formal education, non-formal education and informal education and. Those three educational paths that should be completing each other in order to create the character education. A need to encourage effective communication and sharing values among families, schools, religious organizations, and education Informal communityfamily education and environment-have an important and strategic role in determining the success of the educational. This is related to the truth that on average, students only enroll about seven hours (less than $30 \%$ of their time per day) in school. Moreover, the learners are in the family and the neighborhood.

We know in informal education, especially in the family environment has not significantly contributed in supporting the achievement of competence and the formation students' characterization. The bustle and work activity of parents that is relatively high, the lack of parents ' understanding of educating children in the family environment, social influences in the environment, and the influence of electronic media could be considered as a negative effect on the development and achievement of the learners. One alternative to overcome these problems is an integrated effort in character education, which is to integrate and optimize the activities of informal education with formal education family environment at school.

The importance effort above, collaborative work between the parties is very necessary. Lecturers as educators in schools should be collaborating with parents and society. However, the collaboration between teachers and students also important. For this importance, teachers initiation indispensable. the family has an important role in character education. The whole members should have perception, attitude, and the same pattern of character development. Parents need to enforce the order of 
conduct and etiquette/manners in strengthening families' character shown to the child behavior. In addition to that, parents need to establish an effective communication with a teacher at the school.

Educational institutions have a huge role in character education. Education is believed as a place to introduce noble values of life; a place for seeding new values that agreed by the community to confront the changes; and preserving the future noble values.

On the campus, character education can be integrated into the learning in each subject. Instructional material relating to norms or values on each subject needs to be developed, explicit, associated with the context of everyday life. Thus, learning the values of character not only on the cognitive level, but touched on internalization, and real practice in the lives of young people in the community daily.

\section{BAHASA INDONESIA'S LECTURE'S FUNCTION IN CHARACTER DEVELOPMENT}

Language has a primary function as a device to communicate and interact. However, Bahasa Indonesia not merely as a device of communication. Indonesian has proven its function as a medium of expression (1) a statement of political attitudes national identity in the Second Youth Congress on October 281928 which declared the recognition of (i) one homeland, the homeland of Indonesia, (ii) one nation, the nation of Indonesia, and (iii) to uphold the national language, Indonesian, and (2) declaration of independence of Indonesia August 17 1975. statement of political stance on the Scientific meeting of Indonesian Language and Literature (PIBSI) XXXV 5.

The Youth Pledge was able to build unifying synergies power independence from Western colonialism. Meanwhile, the statement of the Indonesian independence proved capable of inspiring formed by the union of Asian-African nations against colonialism.

That's a reality that Indonesian as the national language has a big political role, especially as unifying the nation of Indonesia. Indonesian play an important role unification of different forms of the nation, the nation's struggle for independence, the intellectual life of the nation, and a change towards a more advanced and superior civilization. According to that, the effectiveness of Bahasa Indonesia education has an important role and determine of developing intelligence and youth's character development. The improvement of the quality and the vocabulary expansion need to be implemented continuously.

In accordance with the nature of the formation, development of the character of the nation is addressed to learners through language education because the language has a fundamental role as a means of thought and expression and communication. Meanwhile, the character is an expression of the ideas in the form of verbal language (the language through oral or writing). When expression was obtained responses of others, there was communication. In addition, in the form of verbal language, the expression of the ideas it can also be tangible actions. As the result of thinking is strongly influenced by the power of language, without a mastery of human language is not capable of thought, expression, and to communicate effectively. Therefore, the establishment of a national character for generations of coatings made through language learning in the school system and involving all stakeholders in the school environment, such as teachers, students, principals, and school administration officials.

\section{BAHASA INDONESIA'S LECTURER'S FUNCTION THAT IS CHARACTERISED AND INSPIRING}

PBM Learning is essentially an educational interaction between students and teachers and other sources of learning to reach intended purpose. Learning is an active activity of students in constructing meaning. Therefore, teachers need to encourage students to use its authority in establishing the idea. The responsibility of learning is within the student, but the teacher is responsible for creating situations that encourage initiative, motivation and responsibility of students for lifelong learning.

Similarly affirmed in Pascal 1 of [7] states that teachers have the primary task of educating, teaching, guiding, directing, train, assess, and evaluate students.

students will continue to learn actively if the conditions of learning made become fun, convenient, and far from behavior painful feelings. The fun learning atmosphere is needed because the brain will not work optimally in a depressed state.

For that, as affirmed by [8], the teacher has the important task of guiding and facilitating students to learn Lecturer should strive to continuously improve the ability to become a lecturer great to inspire students so that they are actively involved in, cooperative and responsible in lecture [9] suggests five potential students to teachers is directed. Five abilities it is dignity (dignity), energy (energy), self-management (selfmanagement), community (community), and awareness (awareness) abbreviated DESCA. Students are born with the ability to live with dignity, to perform all his duties with energy, conduct themselves with proper management, working with a community of others, and to care about everything that happens around them.

The innate ability to live and work in dignity, so it is with us. In addition, deep within the students, they want to live and work with dignity. They do not want to be belittled, demeaned, considered unimportant, and worthless. To that end, the teacher's task if it is to inspire students to become active learners as a whole is running a class in a convenient way and sharpening. Indonesian Teachers should not demand too fast results. Lecturers have a lot to give languaging exercises and activities to the student literary appreciation. To achieve better learning outcomes would need to create good learning process and meaningful. Students have the natural ability to live life with passion.

They want to live a life full of energy. They feel miserable if it should remain sitting or standing for too long, without much activity. Therefore, teachers need to be members of many challenges to the students to express themselves with language. 
They are conditioned to practice the four language skills with passion.

Holistically, people have the ability of self-management and teachers should develop the capability to either the students. Lecturers provide flexibility to students to choose their own colleagues to do the task; enter multiple choices in each job or task was given to the students, and ask students to create a personal plan to improve language skills through portfolio assessment. Students are encouraged to be independent in developing language skills.

Students as we all, have the ability to associate and relate well to others. If a teacher wants to improve students' ability to work together, teachers need to implement a learning community. Cooperative learning is very necessary to apply to learning the language. Students have the innate nature to always want to know. They were not born to become a bore. Instead, they have the nature to avoid boredom. Therefore, teachers should strive to create a situation of students in the ready and full of curiosity. Teachers should always strive to improve student inquisitiveness. An inductive approach to learning is better adapted than the deductive approach. Application of learning approach that emphasizes the student's ability to reconstruct the knowledge, skills, and attitudes are highly recommended. Students are constantly encouraged to have the ability to ask and find. Learning that is active, effective, and fun demanding role of lecturers as creative and dynamic facilitators. Lecturers are expected to use learning strategies or approaches and varied class management, class set in a pleasant atmosphere, developing material according to the needs of learning, and preparing and using instructional media are interesting and challenging students' active participation in the activities of communicating.

Lecturers need to update the learning process, trying to see him as something more than just the transfer of information or knowledge. In the learning activities that are firmly attached to the elements of compassion, empathy, humility, creativity, sincerity, and other superior characters. These elements can easily be found in the literature. Therefore, the integration of language and literacy learning are indispensable.

To be an inspiring lecturer, the teacher should have a passionate desire to see the learners grow, metamorphose and become perfected beings who are able to empower and actualize himself. That is what needs to be owned by the teachers. This is really the values that will make us not just ordinary teacher, but a great teacher, and even become a legend, which will be remembered by many of our learner's souls of all time [10].

More by [10] thrusting tips $8 \mathrm{~K}$ (Compassion, Concern, Patience, creativity, humility, wisdom, commitment, and honesty). To become a great teacher ("very teacher") those tips are, in my opinion, need to be supplemented with $3 \mathrm{~K}$, ie, Modeling, Authenticity, and Cooperation. Many other positive characters, such as awareness (the ability to empathize), patience, creativity, humility, wisdom, and others. A teacher who has this character obviously will be much loved by the learners. Many souls are lightened. He illuminates dim conscience; the spirit and passion ignite college.
Modeling is an indispensable presence in the practice of education and learning. In a study, there needs to be a model that can be replicated. Students will master the new skills well if the teacher gives an example and a model to be viewed and emulated. However, keep in mind that the teacher is not the only model. Models can be designed to engage students. The model can also be brought in from outside, either in the form of the figure of people, activities, as well as the specific work. In the context of Indonesian language learning, the ability of teachers become tokens in the act of speaking and compose indispensable.

Teachers should be able to present themselves to the students as a teacher who likes to read, skills, talk, and have the ability to write. Students need to get the confidence that a teacher is a person who has a presentation. That kind of teacher will encourage students to have a positive attitude towards Bahasa Indonesia. Exemplary will also enhance students' interest in learning Bahasa Indonesia and respect Bahasa Indonesia, both as a symbol of national identity and pride of the nation, to unite the nation that inherited from the period of independence as a perjuanagan character pillar of the Indonesian nation. The exemplary will also be a plant for students to love and appreciate the literature and culture of Indonesia.

Lecturer, with their language skills, will also be able to inspire students. The language used by teachers when carrying out their duties should be able to give a different feel. Words that are selected and used should be able to inspire students to become students engaged actively and constructively in learning. A careful choice of words in the language to be able to effect stimulation and motivation in students. Watch and compare the following example. (1) the Regulation and its consequences in this class are as follows. If you cannot abide by these rules, you will get a penalty. (2) I wish we could have mutual respect in this class, and I'll begin with a promise to cherish you. If you feel I break my word, go directly to speak to me personally so that I could learn to behave better.

Compare also the following sentences. (3) I want you to do it with as good as you can do (4) How do you motivate yourself to be able to do it truly come from your sincere hearts.

\section{CONCLUSION}

The conclusion from the above description is clear that to create students' and generation characterized required a characterized teacher; teachers who are not only intellectually, but also emotionally and spiritually capabilities. The formation of character learners requires professional lecturers. Indonesian professional lecturers none other than the teacher who (1) have a broad knowledge of the language; (2) have the language skills; (3) is able to make a good planning; (4) able to carry out learning activities well, is able to carry out learning approaches and methods appropriate to the objectives to be achieved, (5) empowers learners in learning; (6) has a quality culture, based on the professionalism of teacher behavior; (7) has a disclosure; (8) strive to increase student participation in learning; (9) the assessment and continuous improvement; (10) to establish communication and interaction with students; (11) have accountability; (12) being critical and dare resist the will 
of the less instructive; (13) be creative in building and produce work of education;

And (14) dare to convince the head of the Rector, Parents, Community to side with them to against some of the Innovation Education the Educational That tends to Hard accepted by general people. Lecturer Must be partner WITH Parent and Student And a good Environment that could inspire students The CAN inspire and be a good role model role in everyday life.

The preferred spelling of the word "acknowledgment" in America is without an "e" after the "g." Avoid the stilted expression "one of us (R. B. G.) thanks ...". Instead, try "R. B. G. thanks...". Put sponsor acknowledgments in the unnumbered footnote on the first page.

\section{REFERENCES}

[1] Undang-Undang Republik Indonesia Nomor 20 Tahun 2003 tentang Sistem Pendidikan Nasional.

[2] Peraturan Menteri Pendidikan Nasional Republik Indonesia Republik Indonesia Nomor 23 Tahun 2006 tentang Standar Kompetensi Lulusan untuk Satuan Pendidikan Dasar dan Menengah. Ulang Tahunnya yang ke75. Jakarta: Yayasan Obor Indonesia.

[3] Suyanto. (2010). "Urgensi Pendidikan Karakter".

[4] Kemendiknas. (2010). Bahan Pelatihan: Penguatan Metodologi Pembelajaran Berdasarkan Nilai-nilai Budaya untuk Membentuk Daya Saing dan Karakter Bangsa. Jakarta: Pusat Kurikulum dan Perbukuan.

[5] Kesuma, Dharma, Cepi Triatna, dan Johan Permana. (2011). Pendidikan Karakter Kajian Teori dan Praktik di Sekolah. Bandung: PT Remaja Rosdakarya.

[6] Lickona, Thomas. (1996). "Eleven Principles of Effective Character Education" dalam Journal of Moral Education. Vol. 25, No. 1, 93 - 100.

[7] Undang-Undang Republik Indonesia Nomor 14 Tahun 2005 tentang Guru dan Dosen.

[8] Brown, H. Douglas. (2000). Principles of Language Learning and Teaching, Fourth Edition. $\quad$ Englewood Cliffs, NJ.: Prentice Hall Regents.

[9] Harmin,Merrill dan Toth, Melanie. (2012). Pembelajaran Aktif yang Menginspirasi, Buku Pegangan Lengkap untuk Guru Masa Kini, terj Bethari Anissa Ismayasari. Jakarta: Indeks.

[10] Dani Ronnie M. (2006). The Power of Emotional \& Adversity Quotient for Teachers: Menghadirkan Prinsip-Prinsip Kecerdasan Emosional dan Adversitas dalam Kegiatan Belajar Mengajar. Jakarta: Penerbit Hikmah (PT Mizan Publika). 